\title{
FREEDOM OF RELIGION IN QUR'ANIC PERSPECTIVES: THE INCLUSIVE INTERPRETATIONS OF CONTEMPORARY MUSLIM SCHOLARS
}

\author{
Umi Sumbulah \\ State Islamic University (UIN) Maulana Malik Ibrahim Malang \\ umisumbulah@uin-malang.ac.id
}

\begin{abstract}
This article discusses the interpretations of Tabataba'i, Sayyid Qutb and Quraish Shihab on the verses of religious freedom in the Qur'an. Freedom of religion is a principle now accepted by almost all religious communities as a universal norm. As stated in the Qur'an, it includes both internal and external freedom. Its guarantee can be categorized from a theological and sociological perspective. Theologically, it is seen basically from the absence of compulsion in accepting a religion, the freedom to choose a religion or belief, the prohibition of faith under a compulsion, and no power which can force ones to accept a religion. Sociologically, it is seen in ethical relations and social interaction among religious followers, tolerance and peaceful living, and the respect for religious plurality. Tabataba'i and Shihab's interpretations of religious freedom show their consistency in upholding the principle of openness and appreciating the reality of diversity as an indisputable socio-theological fact. While Qutb, his interpretation of the internal freedom of religion is inclusive, but his view of the people of the book (ahl al-kitab) is exclusive, since it is limited to the period before Muhammad's prophethood. This seems to reflect the general attitude of Islamic fundamentalist activists, not to mention the Muslim Brotherhood as a prototype of new Islamic fundamentalism in the modern era. The interpretation of three Muslim scholars on religious freedom can serve as a normative basis for building harmony in diversity in the contemporary era. The inclusive interpretations of Tabataba'i, Qutb, and Shihab on the verses dealing with the freedom of religion can serve as a normative basis for building harmony in diversity in the contemporary era.
\end{abstract}

Keywords: Freedom of religion, religious communities, respect, tolerance

\section{Introduction}

In the context of Islam, the freedom of religion is commonly based on Qur'anic verses and hadith of the Prophet. It includes external and internal freedom. External freedom is a freedom for a person to accept or refuse a religion. Internal freedom has two meanings: the freedom for one to choose sects, madzhab, and classes within a religion; and the freedom to commit to religious teachings. Therefore, if a person has decided to choose a particular religion, then he must commit to maintain and implement its religious teachings well (Shihab, 1998: 187-221).

Islam teaches the freedom of religion and tolerance. Prophet Muhammad never taught his followers to insult other beliefs and religions (Hamdan, 2003: 182). The concept of religious freedom can not be separated from human rights, especially the right to think and follow the tendencies of conscience. Religion is special and comes from the conscience (Shihab, 1992: 209). Religion is a private-individual spiritual experience. Freedom of religion is the right of individuals to be respected in the context of religious life in a pluralistic society. Hassan's (1992) study on human rights perspective of the Qur'an, religious freedom is one of the 8 basic rights guaranteed by the Qur'an, namely right lo life, right to respect, right to justice, right to freedom, right to privacy, right to 
protection from slander, backbiting, and ridicule, right to the good life, and other rights.

Saeed and Saeed (2011: 11) argue that there are two kinds of freedom related to religion: first, the freedom to defend or replace religion or belief, including the freedom of the individual to maintain his religion and belief (inner freedom) embraced or not religious though. Second, the freedom to manifest religion, that everyone is permitted to practice his religion through worship, practice and religious teaching (Arifin 2015: 299). This article shows that: 1) religious freedom in the Qur'an is categorized into theological and sociological dimensions; 2) Thatbathabei and Shihab consistently provide an inclusive interpretation of religious freedom, while Qutb seems inconsistent in its interpretation of it.

Religious plurality has a close relationship with religious freedom. This can be seen in several verses of the Qur'an that appreciate diversity, as well as to give appreciation for the diversity. Different scenes can be seen in the religious attitudes shown by the religious community from time to time. Studies on religions show three religious attitudes as an embryo of pluralism theory. They are exclusivism, inclusivism, and pluralism-parallelism (Rachman, 2001: 1). The exclusivism holds that certain religion is the right one which offers salvation, believes in single salvation principle, and views others as wrong religions. It dominates the religious attitudes of the religious communities from time to time. On the other hand, inclusivism believes that truth does not only belong to particular religion, but it can also be found in other religions. It teaches to believe a religion and respect other religions. The pluralismparallelism believes that all religions are parallel similar and true. These religious attitudes are found in the traditions of Abrahamic religions. In the context of Islam, the Prophet practiced the inclusivism when he became a political and religious leader in Medina. He gave an equal protection and rights for other religious followers as long as they are not against Islam. This socio-theological commitment, summarized in Mithaq Madinah, was compiled by involving all elements of Medina. The Prophet"s companion also conducted the act of respecting other religions. Some of their political expansion successes were not followed by the success of their preaches (da'wah) quantitatively in the form of increasing the number of Muslims. It is due to the fact that they respected the freedom of religion and other religions.

\section{Method}

The research was conducted thematically based on verses that respected other religions and guaranteed freedom of religion. The meaning of these verses is based on the interpretation of contemporary mufassirs in the books of their works. The election of three mufassirs, namely Tabataba'i in al-Mizan fi Tafsir al-Qur'an, Qutb in fi Dzilal alQur'an and Shihab in Tafsir al-Misbah, is based on consideration, first: Tabataba'i is one of the Shia scholars whose thoughts are not alone influences the next Shiite thinkers in Iran but also the Sunni thinkers. Qutb is an activist figure of the Muslim Brotherhood, which has an influence on the thinking and movement of Islamic fundamentalism of the modern era. Shihab is the first Indonesian mufassir of Al-Azhar graduates whose thinking influences the discourse of contemporary tafsir, especially among moderate Muslim thinkers in the country. Secondly, these three mufassirs use the same method of tahlili interpretation by incorporating philosophical, social, cultural, linguistic and literary approaches, as well as the various socio-historical contexts that form the background of a Qur'anic text.

\section{Result and Discussion}

The results show that the verses on freedom of religion interpreted by 
contemporary Muslim scholars in the Sunni and Shia schools can be categorized into theological and sociological perspectives. This inclusive religious attitude is consistently reflected in the interpretations of Tabataba'i and Shihab, while Qutb's interpretation appears less consistent, especially when interpreting the book ahlul, along with its legal relations and implications. This inclusive interpretation is needed in building the harmony of religions.

\section{Theological Dimension of Freedom of Religion}

Theologically, the guarantee of religious freedom is seen in the principle of the absence of compulsion in religion, the guarantee of choosing religion or belief, the prohibition of faith in compulsion, and no power which can force one to follow a religion.

First, there is no compulsion in religion (Qur'an, 2: 256). This verse asserts that there is no compulsion in accepting religion. God wants everyone to feel peace. Therefore, this religion is called Islam, which means peace. Peace can not be achieved by person who has no peaceful soul. Therefore there is no compulsion in accepting Islamic, because in compulsion there is no peace (Shihab, 2002, vol.1: 515). This verse, according to Tabataba'i (1999, vol.2: 347) also asserts that there is no compulsion in accepting religion. Religion is a combination of scientific knowledge and belief. Belief and faith are issues related to conscience and they are qalbiyah. Thus the things related to the heart can not be formed by compulsion.

Through the study of asbab al-nuzul, with a history of Ibn Abbas, Qutb states that this verse was sent down to Hussein, the men of the Ansar of the son of Salim bin 'Auf. Husen had two children and he asked the Prophet to force his sons to accept Islam. Then, the verse was to respond to the event (Qutb, n.d., vol. 2: 351). This verse explains God admires His servantse ritual, reason and feelings. This prohibition of compelling religion shows that every human being has the right to accept a freedom of religion and belief. Islam as a social order prohibits its follower to force others to accept Islam (Qutb, n.d. vol 1: 270).

Religious freedom is an important part of human rights, which is universally acknowledged by all religions. The prohibition of forcing religious beliefs to a person also becomes a powerful argument that monopolizing religious truth is an incorrect attitude. Therefore, the proselytization in the contemporary era must also be avoided by all religious people (Sumbulah, 2016). The principle of no compulsion in religion, has become a religious commitment respected by Muslim rulers of the classical and middle ages. The most tolerant event in history, for example, was the rescue of the Spanish Savardic Jewish community by the Ottoman Chalif. They were against an ethnic cleansing war of the Spanish Christians after the Spanish reconquista. Had the Ottoman Chalif not given political asylum to them, they would have been extinguished (Hamim, 203: 209).

Second, guarantees the freedom to choose a religion or kufr (Qur"an, 18: 29). Shihab (2002, vol.8: 51-52) explains that the value contained in this verse can not be changed or ignored, because it comes from Allah SWT. Therefore, who will accept it is welcome, and who is reluctant to leave it alone. In the context of this verse, Tabataba'i (1999, vol.13: 300) also explains that Allah says: "Tell the unbelievers that the truth has been revealed from your Lord, then whosoever of you will believe Then believe, but if they will kufr, Allah also invites it ".

For God, faith and kufr will not bring any benefit and harm to Him. Even the benefits will actually return to themselves. Therefore, man is commanded to choose the way he likes, for Allah has also provided a reward for the believers and punishment for the unbelievers. In line with the views of al-Tabataba'i and Shihab, for Qutb (n.d. 2: 
270) the truth will not be blurred. It will remain on a straight path, never to be deflected. This truth will also remain strong without being weaker. Anyone who wants to believe is welcome, and for those who want to deny the truth are also welcome, because the faith or aqeedah is not the possession of a few persons but only belongs to God. In addition, it will never be saved only because of the existence of followers who are not based on ultimate devotion (Tabataba'i, 1999, vol.5: 62).

God grants to human being with reason and will, so that they can make their own choices and take the responsibility. Therefore, it is the essence of freedom in Islam which is accounted to God in the Hereafter. It also deals with the theory of subjective truth. Human are able to find the truth based on their mind and heart. With them, human can choose and follow the path of truth (Hidayat, 2015).

Third, there is no power to force others to accept religion (Qur"ean,88:22). The statement of God that Prophet Muhammad (PBUH)SAW is not a "coercion" (lasta 'alayhim bi musaythir) in the context of this verse, reminds us that the teachings of Islam should not be imposed by anyone, either real or subtle. Therefore, the war involving Muslims aimed not to colonize or control territory (expansion or colonization), but it was merely an effort to liberate, defend and guard against religious values. The aim is that all people can enjoy their basic rights, especially the right to adhere to religion and belief (Shihab, 2002, vol.15: 236). In other words, it can be stated that the ideology and basis of Islamic expansion to some territory at the very beginning of the spread of this religion is a liberation rather than a conquer.

The expansion of Islam into all regions of the world is called futuhat or liberation, not conquest. The success of Islamic $d a^{\prime} w a h$ is not always accompanied by the addition of Muslims in quantitative terms. This is because Muslim rulers do not force the inhabitants of the conquered nations to become Muslims. They are still given the freedom to follow Islam or remain in their original religion. For centuries the Muslim community has established relationships with nations, civilizations, and other religions by implementing an impressive pluralistic politics. One example is the Andalusian or Spanish Islam. At this time, the adherents of these three religions live in harmony. They help each other in bringing about a glorious Islamic civilization. In this context, Dimont (2001: 2) states: "Spain of three religions and one bedroom, a Spain where Muslims, Christians, and Jews shared a brilliant civilisation that blended their culture, bloodlines and religions". Therefore it is not exaggerated when Dimont states that the golden age of Jews coincides with the golden age of Islam.

Under Islamic rule, they got the protection and freedom to embrace their religion and engage in intellectual activity. It proved that even political power has no right to force a person to become a Muslim. The above verse as if to say, you are not a keeper and recorder of their charity. According to Jabir, the Messenger of Allah said: "I am commanded to fight against man until he utters no god but Allah, if they pronounce it, then his blood and his property are preserved unless there is a justified reason for Allah. Then according to Jabir, the Prophet recited the verse: "Remember, you are only a warner not a man of power over them". According to Tabataba'i (1999, vol.8: 30), this verse has the meaning that even the Prophet Muhammad has no ability and power to conquer human heart and force them to accept the faith since the human heart is in the power of God, so that human are not able to conquer it.

Fourth, prohibition of faith in compulsion (Qur"an, 10:99). Allah gives no bless even for the Prophet Muhammad to force people to accept his faith, because the effort will be failed. Even if he made it, God will not accept it, because they accept the faith in coercion and compulsion, whereas Allah only desires sincere faith without selflessness and without coercion (Shihab, 2002, vol.6: 161). This verse asserts that God also does 
not want to make them all believers, so that no one has right to force others to believe. God only accepts faith that comes from conscious choice of conscience, and not from coercion and threat (Tabataba'i, 1999, vol.10: 120). If God willed, Allah will only make a path that leads all His servants to believe in Him as well as angels, but God does not want that so He provides them the ability to choose. With that ability, they are given the right to choose the path to be pursued, so that, faithful or unbelieving is an option that can not be imposed by anyone even by a Messenger of Allah (Qutb, n.d., vol.4: 183). If God had wanted the unity of the people and the opinion, He would have created human without the ability of reason as animals and other inanimate objects, for only then would all be one opinion. Thus, a Muslim can understand the existence of religious diversity and views, for all of that can not be beyond the will of the Divine. If the reason fails to understand why God is doing so, at least the God-ordained reality will not serve as an excuse to force others to follow.

Fifth, freedom of action and responsibility (Qur'an, 6:108). According to Qutb (n.d., 7: 325), the content of the verse above has a clear meaning, as in the sentence: kadzalika zayyanna likulli ummatin 'amalahum. The sentence generally denotes a ban on words that can harass other religions. This verse is also a religious ethic that must be developed in order to maintain the sanctity of religion. If the believers harass the idolaters, they will repay them by despising Allah, the God of the Muslim. The believers have no right to insult the idolaters, for insult will invite the harassment of the polytheists against the Supreme God.

Thus, the most important moral teaching for Muslims is the sincerity and high commitment to the teachings of his religion. The prohibition of cursing gods and other beliefs is a religious guide. It is aimed at maintaining the sanctity of religions, creating a sense of security, and harmonious relationships among religious followers. Everyone will be easily provoked when his religion and beliefs are alluded to (Shihab, 2002, 4: 236) .Jergergensmeyer (2000: xvi) argues that religion often presents symbols that allow for violence, bloodshed and acts of terrorism. When united with other aspects of life, not infrequently religion becomes a tool of legitimacy. In this context, individual religious identities are transformed into communal homogenization. Religion will be a force in generating a religious emotional identity, compared to other social identities. In this context, Kakar's (1998: 192) analysis that religion brings intergroup conflicts with greater emotional intensity and deeper coercive motivation than language, region or olokan to other ethnic identities, finds its relevance. This is because religion is believed to be an ideology, touching the deepest aspect of emotionality for the behavior of its adherents.

\section{Sociological Dimension of Freedom of Religion}

Sociologically, the guarantee of religious freedom is seen in the ethics of relations and social interaction among religious followers. This is seen in the principles of protection of religious activities, the protection of places of worship, the prohibition of disagreement between classes and interfaith, guarantees the treatment and interaction well, upholds equality and justice, the command to compete in goodness, the command to be positive in establishing relationships and cooperating with the community interfaith, the prohibition of arguing with the ahlul book except in a good way, the mission of Islam as a blessing to the world, freedom to act and responsible, tolerance and peaceful living, and an appreciation of religious plurality.

First, the duty of the ummah to protect the house of worship (Qurean, 22: 40). The verse is understood by Shihab (2002, vol.9: 72), through stating that Allah does not want the destruction of houses of worship. Based on this verse, Islamic scholars stipulate that Muslims have an obligation to preserve it. The obligation is not only 
about maintaining mosques, but also guarding the houses of other people's worship, such as churches and synagogues. Although there are Islamic scholars who give strict limits, it can be stated that Islam is a religion that gives freedom of religion, so it becomes the obligation of Muslims to participate actively in preserving and maintaining the freedom of other people in implementing the teachings of their religion. Thus, Muslims are forbidden to disturb them, as Muslims also want them not to be disturbed by anyone. According to Tabataba'i (1999, vol.14: 387), the verse also shows that the war in Islam is one of the provisions of religion that is fitrah. Nevertheless, war is chosen in to preserve the existence of religious society from the threat of enemies who want to extinguish the light of God. In line with Tabataba'i, Qutb (n.d. vol.5: 199) asserts that nothing can save the house of worship except the power of God to reject (the ferocity) it. For Muslim Brotherhood activist, the verse shows that truth cannot sufficiently believe as the opposite of falsehood, but it also takes strength to realize that truth. This is the main principle that can not be replaced as long as humans still recognize their true identity as human beings.

Second, prohibition of disputes between groups and adherents of religion (Qur'ean, 22: 17). The verse implies that all believers of religion and faith who have dispute with one another, will only be judged by God on the Day of Resurrection. God also will give reward based on their deeds (Shihab, 2002, vol.9: 27-28). God will decide what was being disputed by the believers, for God see the truth and falsehood very clearly without being hindered by the veil or anything (Tabataba'i, 1999, vol. 14: 359). This verse also gives a hint that Allah will guide to whomever Allah wants. Allah is the Essence of power over the guidance and action toward the one in fault. God also will calculate for what they have done, for Allah is the All-Seer of all things (Qutb, nd, vol.5: 188). God is the Power of power over the guidance and the one who is in error. Allah also will give a calculation for what they have done, because $\mathrm{He}$ is the All-seeing over all things (Qutb, n.d., vol.5: 188). The prohibition of disputes between classes and religions is also based on the doctrine that God has made way for every religious people, as in Qur'an, 2: 62 and 2:62 dan 5:48, Asad (1980: 67) interpreting the expression of shari'ah means the way to the watering. This term is used by the Qur'an to show that the legal system is necessary for the salvation of society and its spirituality. The term minhaj an open way, which is abstractly defined as "the way of life". Thus, the term shir'ah and minhaj is more limited than the term din. The word "din" means not only the laws relating to the facts of religion, but also the basis of the unchanging spiritual truth which has been taught by every apostle, propagated and recommended to its people, to the diversity of contexts and every development of the culture of a society (Ali: 2003).

Third, guarantees are well treated and interacted (Qur'an, 49: 11-13). Based on these three verses, the most important emphasized in the context of maintaining respect, and tolerance of religion, such as a ban on a gossip as based on Shihab's interpretation of verse 12. Shihab (2002, vol.13: 258) rejects the view of Tabataba'i who understands that the ban on gossip is only valid if the gossiper is a Muslim. From the three verses above, there are several passages that Tabataba'i understood as affirmation of the believers. According to Shihab (2002, vol.13: 259), the word akh does not necessarily mean a brother or sister. Even the Qur'an affirms the word "seagama" if it intends to remove the impression of "unreligious fraternity" as contained in the Qur'an, 9:11. According to this Indonesian commentator, gossip is an unjust treatment, while religion commands people to uphold justice for anyone, without being limited by race, ethnicity and religion, even to non-believers. Thus, it can be ascertained that gossip is a bad act that cannot be punished by religion. In verse 11, the paragraph of the verse wa man lam yatub, according to him is the affirmation that 
the believers always acknowledge the disobedience done (Qutb, n.d., Vol.18: 326). The interpretation of Qutb (n.d., vol.6: 499) of verse 11, states that the prohibition of mutual disdain between one people and another is due to the subjective judgment of human beings. This subjective judgment may be different from God's judgment, since there is nothing hidden for God. In verse 12, Qutb (n.d., vol.6: 500) argues that this verse aims to prevent the "pollution" of the human heart through bad prejudices. This verse also becomes the basis in the life of society, so that we cannot easily punish someone based only on prejudice. The interpretation of Qutb (n.d., vol.7: 3) of verse 13 explains that the diverse human beings come from the same source, so it is not deserving of enmity. Diversity is a spirit to maintain unity and spirit to support one another.

Fourth, the command to uphold equality and uphold justice (Qur"an, 5: 8). The affirmation in this verse that justice is closer to piety is closely related to the previous verse about God's permission for Muslim men to marry non-Muslim women (ahl alkitab). Thus, this verse is appropriate when the permission is followed by an order maintain taqwa/piety (Shihab, 2002, vol.3: 38). This verse aims to prevent the occurrence of tyranny in the testimony caused by enmity between a witness and something to be witnessed. According to Qutb (n.d., vol.5: 241), this command is generally accepted, even against an enemy. According to Hamka (n.d., vol. 6: 182), being a fair witness means that a believer who is asked for testimony in a case should give a true testimony although the testimony may benefit a person who is hated and harms a loved one. A fair testimony means not distorting facts and truths, only because of the influence of affection or hate, because of the opponent or friend, because of the awareness of one"s wealth, or because of feeling sorry for one"s poverty. Telling a matter honestly is actually justice. In the context of justice, Hamka extends the meaning of a fair testimony to ahlu dhimma. This verse, according to Qutb (n.d., vol.2: 325), relates to God's prohibition against hostile people who have prevented Muslims from entering the mosque of masjidil haram. In this context, Allah affirms that Muslimes hatred against them does not prevent them from upholding justice against them.

Fifth, command to compete in goodness (Qur'an, 5: 48). The derivation of the Qur'an as a witness (muhaimin) on the earlier holy books, according to the interpretation of Hamka (nd: VI: 307) is because the Qur'an contains the essence of the teachings in Tawrat and the Bible. This is a warning for Muslims to be careful in accepting the teachings of Tawrat and the Bible conveyed by the adherents now. The continuity of the Islamic message with the ahl al-kitab has taken place since the beginning of the religious growth brought by the Prophet Muhammad. The position of Islam as the successor to the treatise of the earlier prophets is confirmed in existence for example in the Qur'an, 33: 7, 40:78 and 33:40. In this context, the Prophet (PBUH) illustrates in a hadith about an imperfect building because it is less than a brick. Like the building, it was finished by the prophets who preceded it and only one brick was not installed in one corner. The people who came around the building admired its beauty, but they regretted the unfinished part of the building. The Prophet declared that he was a brick which was then installed in that one less corner and made the building perfect (Bukhari, 1994:196). In this context, Asad (1980: 167) mentions that one of the most important themes of Islamic doctrine is the historical continuity of the various forms and phases of the divine revelation, in which the essence of all religious teachings is identical, because it proclaims the same belief. According to Shihab (2002, 3: 108), this verse is the basis that God does not want to make all people into one (ummah wahidah), as one opinion, one tendency, even one religion in all principles and details. If God wills, 
God will not grant man the freedom to choose, including the freedom of choosing religion and belief. This verse also implies the existence of differences in Shari'a that apply to certain people. These differences include the laws of the Shari'a whose purpose is to give a test to every human "s life (Tabataba'i, 1999, 5: 360). In addition, this verse also affirms that the Qur'an as the last holy book should serve as a reference in every issue, both regarding inter-religious disputes and individual life issues as a Muslim. In this context, Qutb (n.d., 2: 381) argues that a view is useless if it is not based on the Qur'an.

Sixth, command in cooperation with other religious communities (Qur"an, 60: 8). This verse outlines the basic principles of the interaction between Muslims and nonMuslims. In this context, God does not forbid Muslims to do a good and be fair to ahl al-kitab. Thus, if in social interaction some Muslims are on the right side while the others are on the wrong side, then we must defend and win them over (Shihab, 2002, 14: 168). This verse explains that God does not forbid Muslims to treat and respect nonMuslims well, as long as they do not fight and chase Muslims away from their homeland/domicile. It is a form of justice demanded by God because God likes justice (Tabataba'i, 1999, vol.19: 243). For Hamka (vol.28: 136), this verse explicitly states that God does not forbid Muslims to get along well and be fair to other groups, whether they are Jews, Christians or idolaters, as long as they do not fight or chase Muslims away from their homelands. Thus, religious differences or beliefs must be separated from the interaction of everyday life. This is because Islam is a religion of peace and a belief that spreads love. Islam also has a rule to guide all humanity into the shadow of God, with full brotherhood and intimacy. Thus, Islam is not a religion that teaches violence and "draws a sword" except for those who threaten and oppose it. Even in this context, Islam provides a moral rule in the form of a command to reconcile justly with other religious people (Qutb, 7: 183).

Seventh, the command to have good argumentation with the ahlul kitab (Qur"ean, 29:46). According to Shihab (2002, 10: 515), a verse about a command to have a good argumentation is supported by a Hadith about the careful and selective attitude to respond any information that comes from the ahl al-kitab (Hadith narrated by Bukhari No. 4485). For Tabathabei $(1999,16: 142)$, the ban to argue with ahlul kitab except in a good way showing that the commendable debate is a debate that does not cause hatred and humiliation. Moreover, in this verse, people who are $d z a l i m / b a d$ is placed in istisna' position which shows that they always lead to hostility and disregard ethical debate. So the debate with the tyrants will not lead to the good debate/mujadalah. For Qutb (n.d., 5: 467), doing Islamic preaching wisely with the followers of ahl al-kitab aims to convey the wisdom contained in the message brought by Muhammad. Similarly, it applies to the relationship between the teachings that Muhammad brought with the previous treatises. The necessity to hold tight to this last treatise emerged because it fits and perfects the teachings of the previous treatises of the Prophets. The mission of Islam as a mercy to the world (Qur'an, 21:107). The fact that Prophet Muhammad is sent to be a mercy to the whole of the world means that the teachings of Islam have become a mercy for human life and all beings as a whole. This is because the word 'alam' means a collection of the living creatures of God, both perfect and limited life. Thus, there are human nature, angelic realm, nature of jinn, animal nature and natural vegetation (Shihab, 2002, 8: 520). This verse also asserts that the Prophet Muhammad is the messenger of God for the whole human community as a whole. This can be seen from the word al-'alamin, which uses the plural form with additional letters alif and lam. Love and grace are the peaks of the generality of the message of Muhammad (PBUH) (Tabataba'i, 1999, 14: 332). For Qutb (n.d., 5: 175), the mercy 
meant by sending Prophet Muhammad into this realm can be realized for the believers as well as those who do not believe, for them to obtain guidance. However, those who will be guided by the presence of the Prophet Muhammad are those who are willing to (get guided). For Madjid (1998: xxvii), the mission of rahmatan li al-'alamin is understood to obtain God's grace, which does not mean that all people must embrace Islam, but anyone can accomplish the mission of Islam as a hanif religion, which is based on monotheism and good deeds. Then one will get the love of God. Thus, Islam does not monopolize a single safety and God"es compassion. This is because the truth and the heterogeneity of religion are the wills of God and they are undeniable sociotheological facts. Therefore, Madjid reminds that pluralism is part of the genuine connection of diversity in the bonds of civilization, in which all religious communities need to converse and cooperate.

Eighth, command to tolerate and live peacefully (Q.S. 109: 1-6). Surah alKafirun, according to Shihab $(2002,15: 582)$ is proof that the absolute religious teachings are the attitude of the soul (internal), it does not demand statements from outsiders who do not believe it. To reinforce his argument, Shihab employs semantic and linguistic analysis of the last verse of this surah as the basis, lakum dinukum waliya din. The precedence of the word "lakum" and "liya" denotes peculiarity, therefore each religion stands alone, apart, and it does not need to be mixed. It supports the statement: "It is not necessary to invite us to worship your god in a year so that you will also worship Allah for a whole year" (Shihab, 15: 581). According to Tabataba'i (1999, 20: 433-434), this verse has two interpretations: 1) in a religious sense, din leads the verse to assert that your religion is for you, not for me; and my religion is for me, not for you; 2) in the meaning of vengeance, din, means: "You will get the vengeance according to what you do, and I will get the vengeance according to what I do". The word "al-kafirun" in this verse shows that they are not believers and non-believers, so an agreement is impossible. In this context, religious freedom is internally applicable to the adherents of that religion, without comparing and blaming other religions. Different religions can still have mutual dialogue, although it is not about theological debate. This understanding differs from the interpretation of Qutb (nd, 8: 117), which is based on the last sentence of the verse as if to say: "I am here while you are there, there is no way to meet (in one sense)."

Ninth, recognition of the reality of religious plurality (Qurean, 2: 62). According to Shihab's interpretation (2002, vol.1: 208-209), heaven and hell are God's prerogatives that every religious person must recognize. The right does not make all believers equal before God. Harmonious and peaceful life of the followers of religion is absolute because it is the guidance of religion, but not at the expense of/sacrificing religious teachings. A harmonious and peaceful life can be achieved by being submissive to God concerning the decision in the future on the religion decided as true and wrong. All religious people must let the decisions and final determination of who is endowed with peace and heaven, and whoever grieves because of hell. This verse asserts that adherents of a particular religion are not entitled to monopolize the truth and determine that they are the only survivors, such as those who say they will not see Paradise except Jews or Christians. This is because one's glory and pleasure are measured only by the essence of his faith in God, the last day and his pious deeds (Tabataba'i, 1999, 1: 192). To Qutb (n.d., 1:48), this verse specifies that anyone who believes in Allah, the Last Day, and good deeds one does. Those mentioned are not entitled to get the reward from Allah, have no fear and sadness.This was true before Muhammad's prophethood, whereas, after the the Prophet came,one's faith is measured by the last descended Shari'a. 
Tabataba'i and Shihab do not seem to limit the truth only to the message that prophet Muhammad brought. The inclusive religious thought of the two figures seems different from the religious thought of Qutb which confines the truths of Judaism and Christianity only until the Prophet Muhammad is sent as the last messenger and concludes all the treatises of the prophets.

\section{Conclusion}

The Qur'an provides guarantees of religious freedom, both internal and external freedoms. Freedom of religion encompasses both internal and external freedoms and is categorized into theological and sociological dimensions. Theologically, religious freedom involves the individual's dealings with his God, while the sociological dimension is closely related to the individual's relationship with the community of other religions in the context of religious pluralism. The texts on the guarantee of freedom of religion are understood inclusively by both Sunni and Shi'ite religious commentators/interpreters. The Shi'ite mufassir, as represented by Tabataba'i, seems consistent in the context of putting reason and Shia theology as one of the forces in understanding the universal messages of humanity and justice. On the other hand, the interpretation of the Sunni mufassir, represented by Qutb, in general is also inclusive, but his response to the ahlul kitab, is limited only before Muhammad's prophethood. The interpretation of Qutb differs from the interpretation of Tabataba'i and Shihab, which holds that ahlul kitab does not appear at the time limit before Muhammad's prophethood, but depends on his monotheistic teaching principle, believing in the end and performing good deeds. Nevertheless, the interpretation of these three scholars creates a commitment to lay the teachings on religiosity and religious freedom as an essential part of every individual's right which has to be respected and upheld.

\section{References}

Ali, Mukti.2003 "Pluralisme: Budaya Belajar Memahami Ajaran Agama," in Ijtihad: Jurnal Wacana Hukum Islam dan Kemanusiaan. Nomor 1 Tahun III/Januari-Juni.

Arifin, Syamsul. 2015. Studi Islam Kontemporer: Arus Radikalisasi dan Multikulturalisme di Indonesia. Malang: Intrans Publishing.

Asad, Muhammad.1980. The Message of the Qur'an.Gibraltar: Dar al-Andalus.

Boullata, Issa J. 1995. Fa-stabiqu al-Khayrat: A Qur'anic Principle of Interfaith, in Yvonne Haddad dan Wadi Z. Haddad (ed.), Christian-Muslim Encounters. Gainesville: University of Florida Press, 43-53.

Al-Bukhari, al-Imam. 1999. "Shahih al-Bukhari", in Mawsu'ah al-Kutub al-Tis'ah (CDROM), versi 2.0. Makkah: Global Islamic Software.

Dimont, Max I. 2001. The Jews in America: The Roots, History and Destiny of American Jews. Chicago: Olmstead Press.

Hamdan. 2003. Riuh di Beranda Satu: Peta Kerukunan Umat Beragama di Indonesia. Jakarta: Balitbang Depag dan Puslitbang Kehidupan Beragama.

Hamim, Thoha.2003. NU di Bawah Tekanan Problematika Kontemporer: Dialektika Kehidupan Politik, Agama, Pendidikan dan Sosial Masyarakat Muslim. Surabaya: Diantama.

Hamka. n.d. Tafsir al-Azhar. Surabaya: Yayasan Latimojong. Vol. VI dan XXVIII.

Hassan, Riffat. 1992. "On Human Rights and the Qur'anic Perspective". Muslims in Dialogue: The Evolution of a Dilogue. Leonard Swidler (ed.), The Edwin Mellen Press, Lewiston, pp. 463-495. 
Hidayat, Komaruddin. 2015. Satu Tuhan Beragam Agama- Penjara-penjara Kehidupan (Snackbook). Jakarta: Noura Books (PT Mizan Publika).

Juergensmeyer, Mark. 2000. Terror in the Mind of God: The Global Rise of Religious Violence.Los Angeles: University of California Press.

Kakar, Sudhir. 1996. The Colors of Violence Cultural Identities, Religion and Conflict. Chicago: University of Chicago Press.

Madjid, Nurcholis. 1998. Pengantar George B. Grose dan Hubbard, Tiga Agama Satu Tuhan. Bandung: Mizan.

Rachman, Budy Munawar. 2001. Islam Pluralis: Wacana Kesetaraan Kaum Beriman. Jakarta: Paramadina.

Sayyid Quthb. N.d. Fi Dzilal al-Qur'an. http://www.shamela.ws. al-Ishdar Thani versi 2. 11, Vol. 1,2,3,4,5,7,8.

Shihab, M. Quraish. 1998. "Wawasan al-Qur"an tentang Kebebasan Beragama", in Komarudin Hidayat and Ahmad Gaus (ed,), Passing Over Melintas Batas Agama- agama. Jakarta: Gramedia-Paramadina, 187-221.

----------, 2002. Tafsir al-Mishbah: Pesan, Kesan dan Keserasian alQur'an.Jakarta: Lentera Hati,Vol. 1,3,4, 6,8,9,10,13,14, 15.

Sumbulah, Umi. 2016. Muslim-Christian Relation on the Basis of Christian Village in Malang, East Java, Indonesia: Socio-Theological Reconstruction for Building Religious Harmony. Research on Humanities and Social Sciences, 6 (12). pp. 1-7.

Al-Tabataba'i, Al-'Allamah al-Sayyid Muhammad Husein. 1999. Al-Mizan fi Tafsir al-Qur'an. Beirut: Muassasah al-A'lamiy, Vol. 1,2,3,5,7,14,18,19,20. 